\title{
Perbandingan Efektivitas antara Terapi Sinar Tunggal dengan dan Tanpa Kain Putih pada Bayi Berat Lahir Rendah dengan Hiperbilirubinemia
}

Stanislaus Djokomulyanto, Rinawati Rohsiswatmo, Aryono Hendarto

Departemen Ilmu Kesehatan Anak, Fakultas Kedokteran Indonesia/Rumah Sakit Cipto Mangunkusumo, Jakarta

Latar belakang. Terapi sinar adalah terapi utama dalam penanganan hiperbilirubinemia. Meningkatkan intensitas sinar terapi sinar dengan menambahkan kain putih sebagai pemantul dapat meningkatkan efektifitas terapi sinar dan menurunkan kadar bilirubin serum lebih cepat.

Tujuan. Membandingkan efektifitas terapi sinar tunggal dengan dan tanpa kain putih pada bayi berat lahir rendah dengan hiperbilirubinemia.

Metode. Uji klinis acak terkontrol terbuka yang dilakukan di Rumah Sakit Cipto Mangunkusumo dari bulan September sampai November 2012. Didapat 40 bayi berat lahir rendah dengan hiperbilirubinemia. Subjek dibagi dua kelompok secara random, yaitu kelompok terapi sinar dengan kain satin putih (kelompok intervensi, $n=19$ ) dan tanpa kain satin putih (kelompok kontrol, $n=21$ ). Tujuan utama adalah membandingkan perbedaan penurunan kadar bilirubin total dan indirek setelah 6 jam terapi sinar, lama penggunaan terapi sinar, dan efek samping dari terapi sinar.

Hasil. Median (rentang) penurunan kadar bilirubin serum total setelah 6 jam terapi sinar 2,51 mg/dL $(-0,61 ; 5,18)$ pada kelompok intervensi dan $0,85 \mathrm{mg} / \mathrm{dL}(-1,67 ; 5,50)$ kelompok kontrol, $\mathrm{p}=0,029$. Sementara penurunan kadar bilirubin serum indirek setelah 6 jam terapi sinar $2,57 \mathrm{mg} / \mathrm{dL}(-0,42 ; 5,63)$ pada kelompok intervensi dan $0,47 \mathrm{mg} / \mathrm{dL}(-1,63 ; 6,00)$ kelompok kontrol, $\mathrm{p}=0,004$. Penilaian secara Cox proportional hazard regression menunjukkan median dari penggunaan terapi sinar kelompok intervensi, yaitu 12 jam dan 28 jam pada kelompok kontrol. (perubahan chi-square 7,542; p=0,006; hazard ratio 0,565; IK95\%: 0,197-0,762). Selama penelitian, tidak ditemukan efek samping hipertermia, diare, rashes, dan burns.

Kesimpulan. Penggunaan kain satin putih meningkatkan efektifitas terapi sinar pada bayi berat lahir rendah dengan

hiperbilirubinemia indirek tanpa efek samping. Sari Pediatri 2016;18(3):233-9

Kata kunci: bayi berat lahir rendah, kain satin putih, terapi sinar, hiperbilirubinemia

\section{Effectiveness of Single Phototherapy with and without White Satin on Low Birth Weight Infants with Hyperbilirubinemia}

Stanislaus Djokomulyanto, Rinawati Rohsiswatmo, Aryono Hendarto

Background. Hyperbilirubinemia is a condition frequently seen in low birth weight (LBW) babies. Phototeraphy is the main treatment for hyperbilirubinemia. Adding a sheet of white satin as a reflector can increase the effectiveness of phototherapy and lower serum bilirubin levels faster.

Objective. To compare the effectiveness of single phototherapy with and without white satin on LBW infants with hyperbilirubinemia Methods. Randomized controlled trial was done at Cipto Mangunkusumo Hospital from September to November 2012 . There were 40 LBW infants with hyperbilirubinemia during that period. Subjects were randomly divided into two groups, phototherapy with a white satin (intervention group, $\mathrm{n}=19$ ) and phototeraphy without white satin (control group, $\mathrm{n}=21$ ). The main purposes were to compare the decrease in total and indirect bilirubin levels after 6 hours of phototherapy, duration of phototherapy and side effects of phototherapy.

Result. The median (range) decrease in total bilirubin levels after 6 hours of phototherapy were $2.51 \mathrm{mg} / \mathrm{dL}(0.61 ; 5.18)$ in the intervention group and $0.85 \mathrm{mg} / \mathrm{dL}(-1.67 ; 5.50)$ in the control group, $\mathrm{p}=0,029$. Whereas the decrease in indirect bilirubin levels after 6 hours of phototherapy in the intervention group was $2.57 \mathrm{mg} / \mathrm{dL}(-0.42 ; 5.63)$ and in the control group was $0,47 \mathrm{mg} / \mathrm{dL}(-1.63 ; 6.00)$, $\mathrm{p}=0.004$. Assessment with cox proportional hazards regression showed the median of phototherapy duration in the intervention and control group were 12 hours and 28 hours, respectively (chi-square conversion 7.542; $\mathrm{p}=0.006$; hazard ratio 0.565 ; CI 95\% $0.197-0.762$ ). There were no adverse reactions such as hypertermia, diarrhea, rashes, and burns found during this study period.

Conclusion. The use of white satin increase the effectiveness of phototherapy in LBW infants with indirect hyperbilirubinemia without side effects. Sari Pediatri 2016;18(3):233-9

Keywords: low birthweight infants, white satin, phototeraphy, hyperbilirubinemia

Alamat korespondensi: Dr. Stanislaus Djokomuljanto, SpA(K), DR. Dr. Rinawati Rohsiswatmo, Sp.A(K). Divisi Perinatologi. Departemen Ilmu Kesehatan Anak FKUI-RSCM. Email: rinarohsis@gmail.com 
$\mathrm{H}$

iperbilirubinemia sering dijumpai pada bayi baru lahir dan memerlukan perhatian medis. Secara klinis ditemukan perubahan warna kuning pada kulit dan sklera yang disebabkan oleh peningkatan kadar bilirubin serum lebih dari 2 standar deviasi atau lebih dari kadar yang diharapkan (bilirubin serum total $>5$ $\mathrm{mg} / \mathrm{dL}$ ) berdasarkan usia bayi atau $\geq 9$ persentil. ${ }^{1,2}$

Dilaporkan $60 \%$ bayi cukup bulan akan mengalami hiperbilirubinemia dan $80 \%$ terjadi pada bayi kurang bulan. Bayi kurang bulan maupun bayi berat lahir rendah mempunyai angka kejadian tigabelas kali lebih banyak memerlukan perawatan di rumah sakit dan terapi sinar dibandingkan dengan bayi cukup bulan. ${ }^{3}$ Sebagian besar hiperbilirubinemia bersifat fisiologis dan merupakan fenonema transisi normal yang akan menghilang dalam beberapa hari. ${ }^{4}$ Ketakutan yang berlebihan dalam menghadapi keadaan tersebut dapat menimbulkan masalah yang tidak diharapkan, seperti meningkatnya kecemasan ibu, menurunkan aktifitas menyusui, pemberian terapi yang tidak perlu dan biaya yang berlebihan. Di lain pihak, hiperbilirubinemia dapat patologis menimbulkan gangguan yang menetap (ensefalopati bilirubin/ kernikterus) atau menyebabkan kematian, oleh karena itu setiap bayi dengan hiperbilirubinemia dengan kadar bilirubin serum yang tinggi harus mendapat perhatian dan tata laksana yang serius. ${ }^{5}$

Saat ini, terapi utama hiperbilirubinemia adalah terapi sinar. Penggunaan terapi sinar berguna untuk membatasi peningkatan bilirubin serum dan mencegah deposisi bilirubin di jaringan otak. Efektifitas terapi sinar tergantung oleh intensitas sumber cahaya, spektrum cahaya, luas permukaan tubuh yang terpapar sinar, jarak antara bayi dengan sumber sinar dan desain dari terapi sinar. American Academy of Pediatrics menyarankan penggunaan terapi sinar intesif dalam tata laksana hiperbilurubinemia, akan tetapi pemakaian terapi sinar intensif cukup sulit dilakukan karena keterbatasan alat terutama pada pelayanan primer keterbatasan biaya. Terdapat modalitas dalam meningkatkan efektifitas terapi sinar yaitu dengan menambahkan material sebagai pemantul dan pemakaian terapi sinar ganda..$^{6-12}$

Penambahan material sebagai pemantul sangat bermanfaat terutama untuk negara yang sedang berkembang yang mempunyai keterbatasan biaya dalam pengadaan alat terapi sinar sehingga dapat memperpendek masa rawat serta menghemat biaya.
Beberapa penelitian yang bertujuan meningkatkan efektifitas terapi sinar telah dilakukan di beberapa negara seperti Malaysia, Indonesia, India, dan Iran dengan menambahkan material sebagai pemantul mengelilingi terapi sinar, namun penelitian yang dilakukan menggunakan subjek bayi cukup bulan dengan berat lebih dari 2500 gram bukan pada bayi berat lahir rendah. Penelitian ini bertujuan membandingkan penurunan kadar bilirubin serum pada bayi berat lahir rendah pada terapi sinar dengan kain satin putih dengan terapi sinar saja.

\section{Metode}

Penelitian uji klinis acak terbuka untuk membandingkan penurunan kadar bilirubin serum total dan indirek pada terapi sinar tunggal menggunakan kain satin putih dengan terapi sinar tunggal saja dilakukan bayi berat lahir rendah yang mengalami hiperbilirubinemia. Penelitian dilakukan di Unit Perinatal Divisi Perinatologi Rumah Sakit Cipto Mangunkusumo/FKUI Jakarta pada bulan September sampai November 2012. Kriteria inklusi adalah bayi berat lahir rendah yang mempunyai berat antara 20002499 gram yang mengalami hiperbilirubinemia pada usia lebih dari 24 jam sampai 7 hari yang memerlukan terapi sinar berdasarkan American Academy of Pediatrics dan mendapat persetujuan tertulis dari orangtua. Kriteria eksklusi adalah bayi dengan kadar bilirubin terindikasi untuk tranfusi tukar dan terapi sinar intensif, kelainan bawaan, sepsis berat dan hiperbilirubinemia direk. Subjek penelitian 20 bayi untuk masing-masing kelompok. Penelitian ini telah mendapat persetujuan dari Komisi Etik Penelitian FKUI/RSCM.

\section{Cara kerja}

Subjek yang memenuhi kriteria inklusi akan dipilih secara acak dengan sistem randomisasi blok 6. Ran domisasi dilakukan dengan menggunakan komputer dan membagi sampel menjadi dua kelompok, yaitu kelompok A (intervensi) adalah subjek yang mendapat terapi sinar dengan kain satin putih dan kelompok B (kontrol) adalah subjek yang mendapat terapi sinar saja. Setelah mendapat persetujuan tertulis dari orangtua, subjek akan diambil secara random dari amplop tertutup oleh seseorang yang tidak ikut secara aktif dalam 
penelitian ini. Sebelum terapi sinar diberikan, dilakukan pengambilan darah untuk pemeriksaan darah perifer (hemoglobin dan hematokrit), kadar bilirubin serum total dan indirek, golongan darah dan Rhesus. Terapi sinar akan diletakkan dengan jarak $40 \mathrm{~cm}$ dari subjek dengan menggunakan terapi sinar tipe neonate bilirubin phototherapy equipment tipe XHZ-90 menggunakan 4 buah lampu blue fluorescent Philip TL 20W/T2 buatan Jerman sebanyak 2 unit yang mempunyai intensitas cahaya (spectral irradiance) rata-rata sebesar $13.8 \mu \mathrm{W} /$ $\mathrm{cm} 2 / \mathrm{nm}$ dan terapi sinar tipe Yon-don YD8222 S/ N97090902 yang menggunakan 4 buah lampu blue fluorescent Philip TL 20W/T2 buatan Belanda sebanyak 4 unit dengan spectral irradiance rata-rata sebesar $13.75 \mu \mathrm{W} / \mathrm{cm} 2 / \mathrm{nm}$. Kain satin putih akan diletakkan mengelilingi terapi sinar atau inkubator bayi (Gambar $1)$.

Evaluasi kadar bilirubin serum total dan indirek dilakukan setelah 6 jam terapi sinar dan 24 jam bila masih dengan terapi sinar. Subjek penelitian mendapat tambahan cairan $10 \%$ dari kebutuhan cairan baik secara oral maupun intravena. Subjek akan diperiksa secara berkala terhadap suhu tubuh, berat badan, dan tanda-tanda dehidrasi serta mendapat penutup mata. Terapi sinar akan dihentikan apabila kadar bilirubin serum mencapai kadar di bawah dari nilai bilirubin sesuai usia atau ditemukan efek samping berupa hipertermia, dehidrasi, kelainan kulit berat, letargik, atau orangtua menolak meneruskan penelitian.

\section{Analisis data}

Data dimasukkan dalam database komputer dan diolah menggunakan piranti lunak statistical product and service solutions (SPSS) versi 19.0. Penurunan kadar bilirubin serum akan dianalisis dengan uji Mann Whitney dan uji t 2 kelompok tidak berpasangan, sedangkan durasi terapi sinar akan dianalisis dengan analisis kesintasan.

\section{Hasil}

Selama kurun waktu penelitian terdapat 114 bayi lahir dengan berat lahir 2000-2499 g dan 81 bayi mengalami hiperbilirubinemia (71\%) , 47 bayi $(58 \%)$ memerlukan terapi sinar. Tujuh bayi tidak diikutsertakan dalam penelitian ( 4 bayi dengan kelainan bawaan dan 3 bayi mengalami sepsis berat). Dalam proses penelitian 2 bayi drop out karena pulang paksa sebelum evaluasi 6 jam pasca terapi sinar, sehingga didapat 38 bayi sebagai subjek penelitian terdiri dari 18 bayi kelompok intervensi dan 20 bayi pada kelompok kontrol.

Data dasar karakteristik usia subjek terbanyak 2 hari dijumpai pada 17 bayi. Jumlah bayi laki-laki lebih sedikit daripada bayi perempuan. Berat lahir pada kelompok intervensi $2268 \mathrm{~g}$ (SB 170,9) dan pada kelompok kontrol 2177 g (SB 162,3). Rerata kadar bilirubin serum total dan indirek pada kelompok

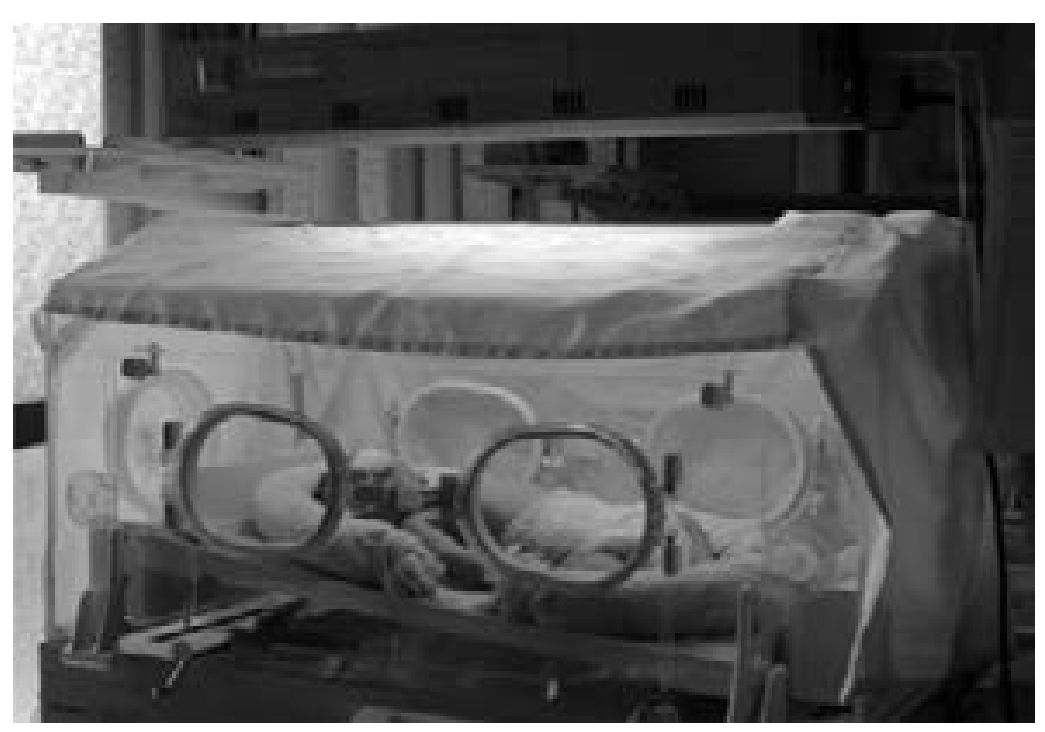

Gambar 1. Kain satin putih yang diletakkan mengelilingi inkubator bayi 
intervensi adalah $13,17 \mathrm{mg} / \mathrm{dL}$ dan $12,52 \mathrm{mg} / \mathrm{dL}$, pada kelompok kontrol 13,43 mg/dL dan $12,49 \mathrm{mg} /$ dL. Karakteristik rerata kadar hemoglobin $16,9 \mathrm{~g} / \mathrm{dl}$ $(3,05)$ pada kelompok intervensi dan $15,4 \mathrm{~g} / \mathrm{dl}(2,44)$ kelompok kontrol (Tabel 1).

Penurunan kadar bilirubin serum total dan indirek setelah 6 jam terapi sinar menunjukkan median (rentang) penurunan kadar bilirubin serum total pada kelompok intervensi $2,51 \mathrm{mg} / \mathrm{dL}$. Kelompok kontrol $0,85 \mathrm{mg} / \mathrm{dL}$ menunjukkan median (rentang) penurunan kadar bilirubin serum indirek pada kelompok intervensi $2,57 \mathrm{mg} / \mathrm{dL}$ dan kelompok

Tabel 1. Karakteristik subjek penelitian

\begin{tabular}{lcc}
\hline & $\begin{array}{c}\text { Intervensi } \\
\text { (terapi sinar dengan } \\
\text { kain satin putih) } \\
\mathrm{n}=19\end{array}$ & $\begin{array}{c}\text { Kontrol } \\
\text { (terapi sinar tanpa kain } \\
\text { satin putih) } \mathrm{n}=21\end{array}$ \\
\hline Usia ( hari) (SB) & $2(0,9)$ & $3(1,7)$ \\
Jenis kelamin & $11(65)$ & $6(35)$ \\
(laki-laki) (n) & $8(35)$ & $15(65)$ \\
(perempuan) (n) & $2268(170,9)$ & $2177(162,3)$ \\
Berat badan lahir (gram) (SB) & $36(1,6)$ & $35(2,1)$ \\
Usia gestasi (minggu) (SB) & $5(63)$ & $3(37)$ \\
ABO inkompatibilitas (n) & & \\
Kadar serum sebelum terapi sinar (mg/dL) SB) & $13,17(1,706)$ & $13,43(1,984)$ \\
$\quad$ Bilirubin total & $12,52(1,562)$ & $12,49(2,403)$ \\
$\quad$ Bilirubin indirek & $36,9(0,19)$ & $36,8(0,14)$ \\
Suhu ( ${ }^{\circ}$ C) (SB) & $16,9(3,05)$ & $15,4(2,44)$ \\
Hemoglobin (g/dL) (SB) & $49,5(9,97)$ & $45,1(7,66)$ \\
Hematokrit $(\%)(\mathrm{SB})$ & $3(75)$ & $1(25)$ \\
Polisitemia $(\mathrm{n})$ & $1(25)$ & $3(75)$ \\
Asfiksia (n) & & \\
\hline
\end{tabular}

Tabel 2. Penurunan kadar bilirubin serum total dan indirek setelah 6 jam terapi sinar

\begin{tabular}{|c|c|c|c|c|}
\hline & Tipe dari terapi sinar & $\mathrm{n}$ & Median & Rerata $\pm S B$ \\
\hline \multirow{2}{*}{ Bilirubin serum total } & $\begin{array}{l}6 \text { jam kelompok } \\
\text { intervensi }(\mathrm{mg} / \mathrm{dL})\end{array}$ & 18 & 2,51 & $2,33 \pm 1,560$ \\
\hline & $\begin{array}{c}6 \text { jam kelompok kontrol } \\
(\mathrm{mg} / \mathrm{dL})\end{array}$ & 20 & 0,85 & $1,20 \pm 1,674$ \\
\hline \multirow{2}{*}{ Bilirubin serum indirek } & $\begin{array}{c}6 \text { jam kelompok } \\
\text { intervensi }(\mathrm{mg} / \mathrm{dL})\end{array}$ & 18 & 2,57 & $2,55 \pm 1,550$ \\
\hline & $\begin{array}{c}6 \text { jam kelompok kontrol } \\
(\mathrm{mg} / \mathrm{dL})\end{array}$ & 20 & 0,47 & $1,06 \pm 1,784$ \\
\hline
\end{tabular}

Uji Mann-Whitney

Tabel 3. Perbandingan rerata intensitas sinar terapi sinar antara terapi sinar dengan dan tanpa kain satin putih

\begin{tabular}{lcccc}
\hline Jenis terapi sinar & $\begin{array}{c}\text { Terapi sinar dengan } \\
\text { kain satin putih } \\
\text { (intervensi) }\end{array}$ & $\begin{array}{c}\text { Terapi sinar tanpa } \\
\text { kain satin putih } \\
\text { (kontrol) }\end{array}$ & IK95\% & $\mathrm{p}$ \\
\hline $\begin{array}{l}\text { Intensitas sinar }(\mu \mathrm{W} / \\
\mathrm{cm} 2 / \mathrm{nm})(\mathrm{SB})\end{array}$ & $16,6(1,18)$ & $13,8(1,87)$ & 1,$867 ; 3,855$ & $<0,0001$ \\
\hline
\end{tabular}




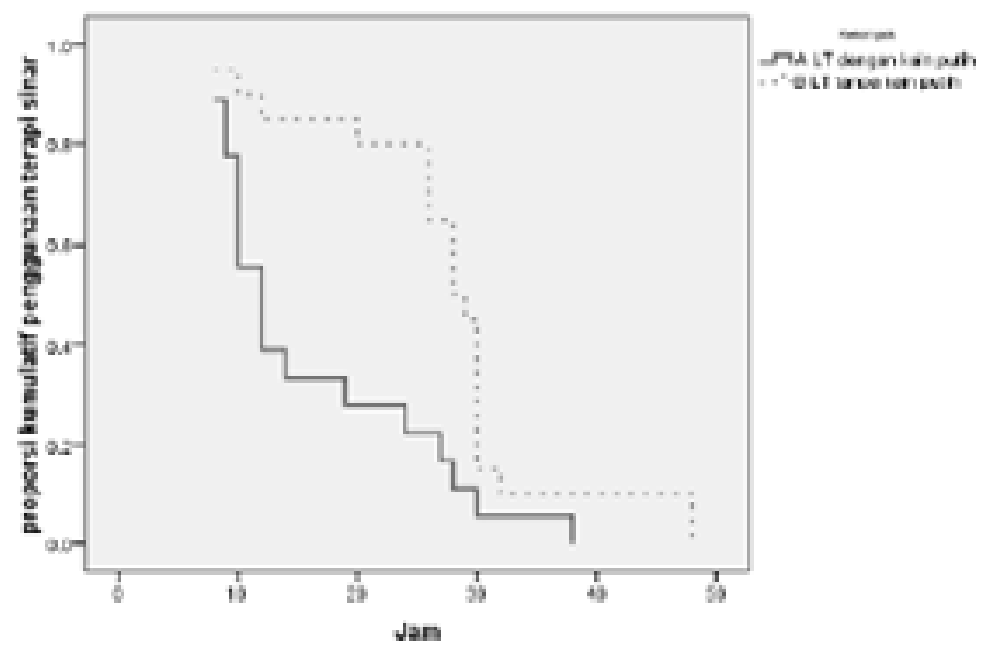

Gambar 2. Kaplan-Meier proporsi kumulatif penggunaan terapi sinar kedua kelompok setelah menilai hasil laboratorium 6 jam terapi sinar

kontrol 0,47 mg/dL (Tabel 2). Data tersebut menunjukkan kecenderungan kelompok intervensi dapat menurunkan kadar bilirubin serum total lebih besar daripada kelompok kontrol.

Pengukuran intensitas sinar terapi sinar dilakukan pada awal penelitian menunjukkan kecenderungan perbedaan pada terapi sinar dengan kain satin putih dibandingkan dengan terapi sinar tanpa kain satin putih (Tabel 3).

Median dari waktu dihentikan terapi sinar adalah duabelas jam (persentil ke-50), 10 jam (persentil ke-25) dan 24 jam (persentil ke-75) pada kelompok intervensi. Sedangkan pada kelompok kontrol adalah 28 jam (persentil ke-50), 26 jam (persentil ke-25) dan 30 jam (persentil ke-75). Penilaian secara Cox Proportional Hazard Regression menunjukkan perbedaan 16 jam penggunaan terapi sinar lebih cepat pada kelompok intervensi (Gambar 2).

\section{Pembahasan}

Mayoritas subjek penelitian berusia rerata 2-3 hari dan ini adalah usia subjek mengalami hiperbilirubinemia dan memerlukan intervensi terapi sinar. Hal ini sejalan dengan pola kenaikkan kadar bilirubin pada bayi berat lahir rendah dan kurang bulan. ${ }^{14}$ Sarici dkk ${ }^{15}$ melaporkan bahwa pada bayi dengan berat lahir rendah dan bayi yang mendekati usia cukup bulan (near term) menunjukkan peningkatan kadar serum bilirubin pada usia 2-3 hari dan mencapai puncak pada usia 4-5 hari. Rerata usia kehamilan dari subjek penelitian ini adalah 35-36 minggu dan 71\% mengalami hiperbilirubinemia, hasil ini lebih rendah dari teori yang menyatakan bahwa sekitar $80 \%$ bayi dengan berat lahir rendah dan kurang bulan akan mengalami hiperbilirubinemia. Terdapat $58 \%$ bayi memerlukan terapi sinar, angka ini lebih tinggi dari laporan Shai Linn $\mathrm{dkk}^{16}$ yang melaporkan $47,5 \%$ bayi dengan berat lahir rendah mengalami hiperbilirubinemia dan memerlukan terapi sinar.

Penurunan kadar bilirubin serum total lebih besar pada kelompok intervensi dibandingkan dengan kelompok kontrol. Penurunan kadar bilirubin serum indirek juga menunjukkan lebih cepat pada kelompok intervensi dibandingkan dengan kelompok kontrol. Hal ini sejalan dengan penelitian terdahulu, yaitu berkisar antara $0,3-0,5 \mathrm{mg} / \mathrm{dL} / \mathrm{jam} .{ }^{6-9}$ Rerata penurunan bilirubin total pada penelitian sebelumnya di Malaysia 1,6 mg/dL setelah 4 jam terapi sinar, di India $2,3 \mathrm{mg} / \mathrm{dL}$ setelah 24 jam terapi sinar, di Iran $6,48 \mathrm{mg} / \mathrm{dL}$ setelah 24 jam terapi sinar. Sementara itu, di Kota Medan dilaporkan penurunan bilirubin total $3,8 \mathrm{mg} / \mathrm{dL}$ setelah 12 jam terapi sinar. ${ }^{6-9}$ Penelitian terdahulu menggunakan subjek bayi cukup bulan dengan berat badan $>2500$ gram. Berbeda dengan terapi sinar intensif yang akan menurunkan kadar bilirubin serum antara $0,5-1 \mathrm{mg} / \mathrm{dL} / \mathrm{jam}$ 4-8 jam setelah terapi sinar intensif. Terapi sinar standar atau konvensional akan menurunkan kadar serum bilirubin 
6\%-20\% dari kadar bilirubin awal dalam waktu 24 jam. ${ }^{2}$

Semakin tinggi intensitas sinar terapi sinar akan semakin cepat penurunan kadar bilirubin serum. ${ }^{2}$ Penelitian kami menunjukkan intesitas sinar terapi sinar dengan kain satin putih lebih tinggi dari terapi sinar saja sebesar 1,2 kali. Penelitian terdahulu di Kelantan, Malaysia, melaporkan hasil peningkatan intensitas terapi sinar 1,5 kali dan penelitian di Medan, Indonesia, sebesar 2 kali. ${ }^{6,12}$ Penurunan kadar bilirubin serum total dan indirek lebih besar pada kelompok intervensi dibandingkan kelompok kontrol. Hal ini sesuai dengan penelitian terdahulu yang dilakukan di Malaysia, Medan, India dan Iran. ${ }^{6-8,12}$ Perbedaan penurunan kadar bilirubin serum dengan kenaikkan intensitas sinar pada penelitian ini mungkin disebabkan oleh kadar bilirubin serum subjek lebih rendah dari penelitian terdahulu yang menggunakan subjek bayi cukup bulan dengan kadar bilirubin serum lebih tinggi. ${ }^{6-8,12}$

Penggunaan terapi sinar dengan kain satin putih menunjukkan waktu lebih singkat, yaitu 16 jam lebih cepat dibandingkan dengan terapi sinar tanpa kain satin putih. Berbeda dengan penelitian di Malaysia yang menunjukkan perbedaan lebih lama yaitu 22 jam. ${ }^{6}$ Selama penelitian ini tidak dijumpai adanya efek samping berupa hipertermia, diare, rashes, burns.

Pada penelitian ini juga tidak mendapatkan rebound jaundice setelah terapi sinar dihentikan dan diamati selama 24-48 jam secara klinis, berbeda dengan laporan penelitian yang terdahulu. ${ }^{13}$ Kemungkinan hal ini karena subjek dengan kadar bilirubin serum yang tinggi atau mendekati tingkat dari tranfusi tukar tidak diikutsertakan dan subjek mengalami sepsis berat serta proses hemolisis.

\section{Kesimpulan}

Penggunaan kain satin putih sebagai pemantul pada terapi sinar mengingkatkan efektivitas terapi sinar dalam menurunkan kadar bilirubin serum, memperpendek masa penggunaan terapi sinar, sehingga dapat mengurangi biaya perawatan dan tidak ada efek samping dalam penggunaan kain satin putih sebagai pemantul pada terapi sinar. Disarankan melanjutkan penelitian untuk menambah jumlah kasus sehingga dapat dianalisis lebih lanjut.

\section{Daftar pustaka}

1. Sukadi A. Hiperbilirubinemia. Dalam: Kosim MS, Yunanto A, Dewi R, Sarosa GI, Usman A, penyunting. Buku Ajar Neonatologi. Edisi 1. Jakarta: IDAI; 2008.h.147-69.

2. American Academy of Pediatrics. Subcommittee on hyperbilirubinemia. Management of hyperbilirubinemia in the newborn infants 35 or more weeks of gestation. Pediatrics 2004; 114:297-316.

3. Maisels MJ. Epidemilogy of neonatal jaundice. Dalam: Maisels MJ, Watchko JK, penyunting. Neonatal jaundice. Harwood academic publishers, New York, Volume 11. 2000.h.37-49.

4. Sukadi A. Hiperbilirubinemia. Dalam: Kosim MS, Yunanto A, Dewi R, Sarosa GI, Usman A, penyunting. Buku Ajar Neonatologi. Edisi 1. Jakarta: IDAI; 2008.h.147-69.

5. Rohsiswanto R. Indikasi terapi sinar pada bayi menyusui yang kuning. Dalam: Suradi R, Hegar B, Partiwi IGAN, Marzuki ANS, Ananta Y, penyunting. Indonesia menyusui. IDAI; 2010. h. 67-75.

6. Djokomuljanto S, Quah BS, Surini Y, Noraida R, Ismail NZ, Hansen TWR, dkk. Efficacy of phototherapy for neonatal jaundice is increased by the use of low-cost white reflecting curtains. Arch Dis Child Fetal Neonatal 2006; 91:F439-42.

7. Salehzadeh F, Rahimi MM, Janhangiri S, Habibzadeh S, Sani NA, Samshirgara M, dkk. Mirror covered tunnel phototherapy increase the efficacy of phototherapy for neonatal jaundice. Iranian J Neonatol 2010;1:20- 3.

8. Sivanandan S, Chawla D, Misra S, Agarwal R, Deorari AK. Effect of sling aplication on efficacy of phototherapy in healthy term neonates with non-hemolytic jaundice: A randomized controlled trial. Indian pediatrics 2009;46:23-8.

9. Azlin E. Efektifitas terapi sinar ganda dan terapi sinar tunggal dengan tirai pemantul sinar pada neonatus yang mengalami jaundice. Sari Pediatri 2011;13:111-16.

10. Sarici SU, Alpay F, Unay B, Ozcan O, Gokcay E. Double versus single phototherapy in term newborns with significant hyperbilirubinemia. J Trop Pediatr 2000;46:36-9.

11. Milyana NS, Tjipta GD, Ali M, Azlin E, Lubis BM, dkk. Effectiveness of single and double phototherapy on indirect hyperbilirubinemia in neonates. Paediatr Indones 2011; 51:316-21.

12. Kurniasih A, Tjipta GD, Ali M, Azlin E, Sianturi P. Effectiveness of phototherapy with reflecting curtains on neonatal jaundice. Paediatr Indones 2011;51:256-61.

13. Kaplan M, Kaplan E, Hammerman C, Algur N, Bromiker $\mathrm{R}$, Schimmel MS, dkk. Post-phototherapy neonatal bilirubin rebound: a potential cause of significant hyperbilirubinaemia. Arch Dis Child 2006; 91:31-4. 
Stanislaus Djokomulyanto dkk: Efektivitas antara terapi sinar tunggal dengan dan tanpa kain putih pada BBLR dengan hiperbilirubinemia

14. Maisels MJ, Newman TB. Predicting hyperbilirubinemia in newborns: the importance of timing. Pediatrics 1999; 103:493-5.

15. Sarici SU, Serdar MA, Korkmaz A, Erdem G, Oran O, Tekinalp G, dkk. Incidence, course, and prediction of hyperbilirubinemia in near term and term newborns. Pediatrics. 2004; 113:775-80.

16. Linn S, Schoenbaum SC, Monson RR, Rosner B, Stubblefield PG, Ryan KJ. Epidemiology of neonatal hyperbilirubinemia. Pediatircs 1985; 75:770-4. 